\title{
THE INFLUENCE OF ANTICHOLINERGIC DRUG SELECTION ON THE EFFECTIVENESS OF OXIMES AGAINST SOMAN-INDUCED SUPRALETHAL POISONING IN MICE
}

\begin{abstract}
Jiř́ Kassa
Purkyně Military Medical Academy, Hradec Králové: Department of Toxicology

Summary: 1. The influence of anticholinergic drugs (atropine, benactyzine, biperiden) on the efficacy of monopyridinium and bispyridinium oximes (HI-6, BI-6, obidoxime, pralidoxime, methoxime) on soman-induced supralethal poisoning was studied in mice. 2. While methoxime combined with benactyzine or biperiden seems to be more efficacious in the elimination of toxic effects of supralethal dose of soman than its combination with atropine, the efficacy of the other oximes studied against soman-induced toxic effects is not significantly influenced by the anticholinergic drug selection. 3 . On the other hand, there are big differences in the effectiveness of oximes tested as to their ability to eliminate toxic effects of soman at supralethal doses. 4 . The findings support the fact that the choice of acetylcholinesterase reactivator is more important than the anticholinergic drug selection for the effectivenes of antidotal mixture in the case of prophylactic administration of antidotes.
\end{abstract}

Key words: Soman; Oximes; Anticholinergic drugs; Acute toxicity; Mice

\section{Introduction}

Despite the entry into force in April 1997 of the Chemical Weapons Convention forbidding the development, production, stockpiling and use of chemical warfare agents, the world has seen a rapid proliferation of such agents (17). The chemical warfare agents include different types of chemicals. The most important groups are nerve agents, highly toxic organophosphorus compounds (OPs) that exert their toxic effects by irreversible inhibiting the enzyme acetylcholinesterase (AChE, EC 3.1.1.7). Unfortunately, certain OPs are rather resistant to the standard antidotal treatment, which consists of anticholinergic drugs to counteract the accumulation of acetylcholine $(\mathrm{ACh})$ and oximes to reactivate OP-inhibited $\mathrm{AChE}(4,14)$.

Soman (O-pinacolyl methylphosphonofluoridate) is an extremely toxic, centrally and peripherally acting nerve agent, which produces ACh accumulation leading to severe respiratory distress, prolonged limbic seizure, generalized convulsions and subsequent neuropathology in the brain (15). It appears to be one of the most resistant OPs to oxime reactivation because of rapid aging and the existence of a soman depot in the poisoned organisms $(1,4,5,6)$.

While the ability of currently used monopyridinium (pralidoxime) and bispyridinium oximes (obidoxime, methoxime) to eliminate toxic effects of soman is rather low, the $\mathrm{H}$ oximes seem to be relatively successful in antagonizing soman poisoning $(9,11,12,19,20)$. Among the series of
$\mathrm{H}$ oximes, the HI-6 has been the most studied because it seems to be the most efficacious oxime, yet found, against toxic effects of soman $(1,7,9,12,18)$. Recently, new asymmetric bispyridinium oxime, designated BI-6, has been synthesized at our Department of Toxicology to improve the efficacy of antidotal treatment of soman poisoning. It is an analogue of the oxime HI-6 that involves transbuten instead of propan linkage between pyridinium rings (3). Although the oxime BI-6 is also successful in antagonizing toxic effects of soman, it has no definite advantages over HI-6 in the antidotal treatment of acute soman poisoning (10).

Not only the choice of oximes but also the anticholinergic drug selection could influence the effectiveness of antidotes against OPs. The OP-induced poisoning is usually treated by an oxime in combination with the anticholinergic drug atropine. Nevertheless, there are other anticholinergic drugs that seem to be suitable adjuncts to oxime treatment of soman-induced poisoning (22). It has been described that some centrally acting cholinolytic drugs such as benactyzine are able to increase the ability of HI-6 to reactivate soman-inhibited AChE in comparison with atropine (8).

The present study compares the effects of currently used oximes (pralidoxime, obidoxime, methoxime) and $\mathrm{H}$ oximes (HI-6, BI-6) in combination with various anticholinergic drugs (atropine, benactyzin, biperiden) against supralethal dose of soman in mice in the case of prophylactic administration of antidotes. 


\section{Methods}

Male mice weighing between 19 and $23 \mathrm{~g}$ were obtained from Konárovice. The animals were maintained in an airconditioned room with light from 07.00 to $19.00 \mathrm{~h}$ and were allowed free access to standard food and tap water. The principles of laboratory animal care were followed and the handling of animals was made under the supervision of the Ethics Committee of Medical Faculty of Charles University and Purkyně Military Medical Academy in Hradec Králové.

Soman of $95 \%$ purity was purchased from Zemianské Kostolany (Slovak Republic). Its purity was assayed by acidimetric titration. The oximes HI- 6 and BI-6 of $98.5 \%$ purity were synthesized at the Department of Toxicology of Purkyně Military Medical Academy in Hradec Králové. All other chemicals and drugs of analytical grade were obtained commercially and used without further purification.

The efficacy of oximes against soman administered intramuscularly (i.m.) at a supralethal dose $\left(240 \mu \mathrm{g} / \mathrm{kg}, 2 \times \mathrm{LD}_{50}\right)$ was determined by the evaluation of their medium efficacy doses $\left(\mathrm{ED}_{50}\right.$ values) and their $95 \%$ confidence limits using probit analysis of death occuring within $24 \mathrm{~h}$ following soman poisoning in at least four groups of six experimental animals (21). In these experiments, the oximes were injected i.m. in combination with one of the anticholinergic drugs used (atropine, benactyzine, biperiden) at equieffective doses $\left(5 \% \mathrm{LD}_{50}\right) 5 \mathrm{~min}$ before challenge of soman. Finally, the safety of oximes administered at the efficacious doses was determined by the calculation of safety ratio $\left(\mathrm{LD}_{50} / \mathrm{ED}_{50}\right.$ value, $\left.\mathrm{SR}\right)$. The acute toxicity of all oximes tested in mice $\left(\mathrm{LD}_{50}\right.$ values) was also evaluated using probit logarithmical analysis (21).

Statistical significance was determined by the use of Student's t-test and differences were considered significant when $\mathrm{p}<0.05$.

\section{Results}

The $\mathrm{LD}_{50}$ values of all oximes tested are shown in Tab. 1 . These values were used for the calculation of the safety of administration of oximes at efficacious doses.

The efficacy of each oxime in combination with various anticholinergic drugs is presented in Table 2. Pralidoxime as well as obidoxime appear to be ineffective against toxic effects of soman administered at supralethal dose regardless of the choice of anticholinergic drug in the case of the administration of pralidoxime and obidoxime at therapeutical doses (below $25 \% \mathrm{LD}_{50}$ ). The effectiveness of $\mathrm{H}$ oximes (HI-6 and BI-6) does not change significantly when they are combined with various anticholinergic drugs. On the contrary, the prophylactic efficacy of methoxime depends on the selection of the anticholinergic drug. The combination of methoxime with benactyzine or biperiden is significantly more efficacious in antagonizing toxic effect of soman than the combination of methoxime with atropine ( $p<$ $0.05)$.
To compare the efficacious doses of oximes studied, capable of elimination of toxic effects of soman at a supralethal dose, $\mathrm{H}$ oximes seem to be significantly more efficacious in antagonizing lethal effects of soman than other oximes tested regardless of the choice of anticholinergic drugs $(p<0.05)($ Tab. 2).

Tab. 1: $\mathrm{LD}_{50}$ values of oximes following i.m. administration in mice

\begin{tabular}{|l|c|}
\hline OXIME & $\mathrm{LD}_{50}(\mathrm{mg} / \mathrm{kg}) \pm 95 \%$ confidence limit \\
Pralidoxime & $263.6(253.7-273.8)$ \\
\hline Obidoxime & $188.4(156.3-208.0)$ \\
\hline Methoxime & $641.8(590.5-716.0)$ \\
\hline HI-6 & $671.3(627.4-718.3)$ \\
\hline BI-6 & $266.3(248.5-285.4)$ \\
\hline
\end{tabular}

Tab. 2: The prophylactic antidotal potency $\left(\mathrm{ED}_{50}\right.$ value) and safety ratio (SR) of oximes in combination with various anticholinergic drugs in soman-poisoned mice. Statistical significance: ${ }^{*} \mathrm{p}<0.05$.

\begin{tabular}{|l|l|c|c|}
\hline OXIME & $\begin{array}{l}\text { Cholinolytic } \\
\text { drug }\end{array}$ & $\begin{array}{c}\mathrm{ED}_{50}(\mathrm{mg} / \mathrm{kg}) \pm 95 \% \\
\text { confidence limits }\end{array}$ & $\begin{array}{c}\mathrm{SR} \\
\left(\mathrm{LD}_{50} / \mathrm{ED}_{50}\right)\end{array}$ \\
\hline PRALI- & Atropine & $>70$ & $<4.0$ \\
DOXIME & Benactyzine & $>70$ & $<4.0$ \\
& Biperiden & $>70$ & $<4.0$ \\
\hline OBI- & Atropine & $>50$ & $<4.0$ \\
DOXIME & Benactyzine & $>50$ & $<4.0$ \\
& Biperiden & $>50$ & $<4.0$ \\
\hline METHO- & Atropine & $105.7(95.5-117.1)$ & 6.1 \\
XIME & Benactyzine & $50.5(33.9-73.0)^{*}$ & 12.7 \\
& Biperiden & $25.8(19.6-34.9)^{*}$ & 26.0 \\
\hline HI-6 & Atropine & $7.2(6.1-8.4)$ & 93.2 \\
& Benactyzine & $7.0(4.2-11.2)$ & 95.6 \\
& Biperiden & $5.9(3.7-9.5)$ & 113.0 \\
\hline BI-6 & Atropine & $11.7(10.1-13.5)$ & 22.8 \\
& Benactyzine & $10.4(8.3-12.8)$ & 18.8 \\
& Biperiden & $5.6(2.8-11.5)$ & 47.4 \\
\hline
\end{tabular}

\section{Discussion}

Nerve agents are still considered to be the most important chemical warfare agents. With the existing threat of the use of chemical weapons not only in military conflicts but also in terroristic attacks, the search for effective protection is in the central concern of different laboratories both civilian and military $(4,16)$.

The effectiveness of oximes against the toxic effects of nerve agents including soman is usually tested in combination with atropine $(13,20)$. Nevertheless, some other anticholinergic drugs (e.g. benactyzine, biperiden) should be more advantageous than atropine for the elimination of toxic effects of nerve agents because of their central antimuscarinic effects $(2,22)$. However, our results do not confirm an influence of anticholinergic drug selection on the effi- 
cacy of oximes in antagonizing the toxic effects of soman at the supralethal dose in the case of the prophylactic administration of antidotes. With the exception of methoxime, the therapeutical effects of oximes was not significantly influenced by the change of anticholinergic drug in antagonizing soman-induced poisoning in mice. The $\mathrm{H}$ oximes, expecially HI-6, were the most efficacious in eliminating soman-induced toxicity regardless of the choice of anticholinergic drug $(9,11)$.

Although benactyzine as well as biperiden seem to be able to increase the ability of methoxime to eliminate soman-induced toxicity in comparison with atropine, methoxime does not reach the effectiveness of $\mathrm{H}$ oximes against soman regardless of the selection of anticholinergic drug (11).

In conclusion, our data indicate that the choice of $\mathrm{AChE}$ reactivators is more important for the survival of soman-poisoned experimental animals than the selection of anticholinergic drugs in the case of prophylactic administration of antidotes.

\section{Acknowledgement}

The author thanks to Mrs J. Petrová for her technical assistance and help with statistical evaluation.

\section{References}

1. Bajgar J. Present view on toxidynamics of soman poisoning. Acta Med (Hradec Králové) 1996;39:101-5.

2. Bajgar J, Fusek J, Vachek J. Treatment and prophylaxis against nerve agent poisoning. ASA Newslett 1994;94-4:10-1.

3. Bielavský J, Kassa J, Elsnerová I, Dejmenk L. Cholinesterase reactivators derived from pyridine-2-carbaldoxime. Coll Czech Chem Commun 1998;63:199-204.

4. Dawson RM. Review of oximes available for the treatment of nerve agent poisoning. J Appl Toxicol 1994; 14:317-31.

5. Fleisher JH, Harris LW. Dealkylation as a mechanism for aging of cholineste- rase after poisoning with pinacolyl methylphosphonofluoridate. Biochem Pharmacol 1965; 14:641-9.

6. Kadar T, Raveh L, Cohen G, Oz N, Baraness I, Balon A, Ashani Z, Shapira S Distribution of ${ }^{3} \mathrm{H}$-soman in mice. Arch Toxicol 1985;58:45-9.
7. Kassa J. Comparison of efficacy of two oximes (HI-6 and obidoxime) in soman poisoning in rats. Toxicology 1995;101:167-74.

8. Kassa J. Importance of cholinolytic drug selection for the efficacy of HI-6 against soman in rats. Toxicology 1997;116:147-52.

9. Kassa J, Cabal J, Bajgar J, Szinicz L. The choice: HI-6, pralidoxime or obidoxime against nerve agents? ASA Newslett 1997;97-4:16-8.

10. Kassa J. A comparison of the efficacy of new asymmetric bispyridinium oxime BI-6 with other oximes (obidoxime, HI-6) against soman in rats. Hum Exp Toxicol 1998; 17:331-5

11. Kassa J, Cabal J. A comparison of the efficacy of a new asymmetric bispyridinium oxime BI- 6 with currently available oximes and $\mathrm{H}$ oximes against soman by in vitro and in vivo methods. Toxicology 1999;132:111-8.

12. Koplovitz I, Stewart JR. A comparison of the efficacy of HI-6 and 2-PAM against soman, tabun, sarin and VX in the rabbit. Toxicol Lett 1994;70:169-79.

13. Koplovitz I, Menton R, Matthew C, Shutz M, Nalls C, Kelly S. Dose-response effects of atropine and HI-6 treatment of organophosphorus poisoning in guineapigs. Drug Chem Toxicol 1995; 18:119-31.

14. Marrs TC. Organophosphate poisoning. Pharmacol Ther 1993;58:51-66

15. McDonough JHJr, Shih T-M. Neuropharmacological mechanisms of nerve agentinduced seizure and neuropathology. Neurosci Biobehav Rev 1997;21: 559-79.

16. Ohtomi S, Takase M, Kumagai F. Sarin poisoning in Japan. A clinical experience in Japan Self Defense Force (JSDF) Central Hospital. Int Rev Arm Ser 1996;69:97-102.

17. Polhuijs M, Langenberg JP, Benschop H. New method for retrospective detection of exposure to organophosphorus anticholinesterases: application to alleged sarin victims of Japanese terrorists. Toxicol Appl Pharmacol 1997;146:156-61.

18. Rousseaux CG, Dua AK. Pharmacology of HI-6, an H series oximes. Can J Physiol Pharmacol 1989;67:1183-9.

19. Shih T-M, Whalley ChE, Valdes JJ. A comparison of cholinergic effects of HI-6 and pralidoxime-2-chloride (2-PAM) in soman poisoning. Toxicol Lett 1991;55:131-47.

20. Shih T-M. Comparison of several oximes on reactivation of soman-inhibited blood, brain and tissue cholinesterase activity in rats. Arch Toxicol 1993;67:637-46.

21. Tallarida R, Murray R. Manual of pharmacological calculation with computer programs. New York: Springer-Verlag, 1987:p.145.

22. Vachek J, Kassa J, Fusek J, Bajgar J. New possibilities of treatment of poisoning with organophosphorus compounds. Sbor věd Prací VLA JEP (Hradec Králové) 1993;116:67-95

Submitted December 2000.

Accepted July 2001.

Doc. MUDr. Jiři Kassa, CSc., Purkyně Military Medical Academy, P.O. Box 35/T,

50001 Hradec Králové, Czech Republic. e-mail: kassa@pmfhk.cz 